ISSN 1678-3921

Journal homepage: www.embrapa.br/pab

For manuscript submission and journal contents, access: www.scielo.br/pab
Flávia Cristina Martins Queiroz Mariano(1凶), Renato Ribeiro de Lima(2) Renata Ribeiro Alvarenga( ${ }^{(3)}$ and Paulo Borges Rodrigues ${ }^{(3)}$

(1) Universidade Federal de São Paulo, Instituto de Ciência e Tecnologia, Unidade Parque Tecnológico, Avenida Cesare Mansueto Giulio Lattes, № 1.201, Eugênio de Mello, CEP 12247-014 São José dos Campos, SP, Brazil.

E-mail: flavia.queiroz@unifesp.br

(2) Universidade Federal de Lavras, Departamento de Estatística, Campus Universitário, Caixa Postal 3.037, CEP 37200-000 Lavras, MG, Brazil. E-mail: rrlima@des.ufla.br

(3) Universidade Federal de Lavras, Departamento de Zootecnia, Caixa Postal 3.037, CEP 37200-000 Lavras, MG, Brazil.

E-mail: renata.alvarenga@dzo.ufla.br, pborges@dzo.ufla.br

$\bowtie$ Corresponding author

Received

December 18, 2018

Accepted

January 29, 2020

How to cite

MARIANO, F.C.M.Q.; LIMA, R.R. de; ALVARENGA, R.R.; RODRIGUES, P.B. Committee neural network and weighted multiple regression to predict the energetic values of poultry feedstuffs. Pesquisa Agropecuária Brasileira, v.55, e01199, 2020. DOI: https://doi.org/10.1590/S1678-3921. pab2020.v55.01199.

\section{Committee neural network and weighted multiple regression to predict the energetic values of poultry feedstuffs}

\begin{abstract}
The objective of this work was to compare the committee neural network (CNN) and weighted multiple linear regression (WMLR) models, in order to estimate the nitrogen-corrected apparent metabolizable energy (AMEn) of poultry feedstuffs. The prediction equation was adjusted by using a WMLR model and the meta-analysis principle. The models were compared by considering the correct prediction percentages, based on the classic prediction intervals and on the highest-probability density intervals, and by using a comparison test for proportions. The accuracy of the models was evaluated based on the values of the mean squared error, coefficient of determination, mean absolute deviation, mean absolute percentage error, and bias. Data from metabolic trials were used to compare the selected models. The committee neural network is the model that showed the highest accuracy of prediction, being recommended as the most accurate model to predict AMEn values for energetic concentrate feedstuffs used by the poultry feed industry.
\end{abstract}

Index terms: broilers, highest-probability density interval, meta-analysis, metabolizable energy, percentage of success.

\section{Comitê de redes neurais e regressão múltipla ponderada para a predição de valores energéticos de alimentos para aves de corte}

Resumo - O objetivo deste trabalho foi comparar o modelo comitê de redes neurais e o modelo de regressão linear múltipla ponderada (RLMP), para estimar a energia metabolizável aparente corrigida por nitrogênio (EMAn) de alimentos para aves. A equação de predição foi ajustada por RLMP e pelo princípio da meta-análise. Os modelos foram comparados tendo-se considerando as percentagens de acerto de predição, com base em intervalos de predição clássicos e intervalos de credibilidade da máxima densidade de probabilidade, e utilizado um teste para comparação de proporções. A acurácia dos modelos foi avaliada com base nos valores de erro médio quadrático, coeficiente de determinação, desvio médio absoluto, erro percentual absoluto médio e viés. Dados provenientes de ensaios metabólicos foram utilizados na comparação dos modelos selecionados. O comitê de redes neurais é o modelo que forneceu predições mais acuradas, sendo recomendado como o de maior acurácia, para prever os valores de EMAn de alimentos concentrados utilizados na indústria alimentícia para aves.

Termos para indexação: frangos de corte, intervalo de credibilidade da máxima probabilidade, meta-análise, energia metabolizável, percentagem de acerto. 


\section{Introduction}

The diversity of feedstuffs and their byproducts used in the formulation of poultry feeds lead to the need of a precise knowledge of the chemical composition and the metabolizable energy values of feedstuffs to allow of an adequate supply of energy to the animals. The chemical composition determination is much easier and less costly than determining the metabolizable energy of feedstuffs. One of the most direct ways to determine the metabolizable energy is to use prediction equations (Nascimento et al., 2011).

Classical statistical methods have been applied to obtain prediction equations of the nitrogen-corrected apparent metabolizable energy (AMEn) of poultry feeds. In these equations, the energy values of the feedstuffs are established according to their chemical compositions. In the methods used to obtain these prediction equations two ways can be considered to develop a multiple linear regression, as follows: using a classical multiple regression analysis without any restriction or weighting (Rodrigues et al., 2002); or using the principle of meta-analysis, in which homogeneous groups are established as weighting factors (Nascimento et al., 2009; Mariano et al., 2012).

Artificial neural network (ANN) models have recently been used in the prediction of energy values of feedstuffs for poultry (Perai et al., 2010; Mariano et al., 2013). Due to these models' great capacity of learning from examples and generalizing the learned information, as well as of giving coherent answers to unknown data, it is possible to state that the application of an ANN goes beyond simply mapping relations of input and output. For this reason, statistic methods and ANN methods have competed with each other for space in the construction of models in several areas (Shi et al., 2012; Anyaeche \& Ighravwe, 2013). ANN models have also shown superior performance to regression methods in the area of animal production and nutrition (Ahmadi \& Golian, 2010; Perai et al., 2010; Wang et al., 2012).

However, to obtain even more accurate results from ANN models, it is recommended the use of a committee networks. A committee network represents the aggregation of more than one component or network to reach a global solution that is supposedly superior to that obtained by any of the isolated components (Haykin, 2007). The goal of a committee network is to increase the capacity of estimators' generalization, avoiding the over-adjustment of data and convergence of the network to a local minimum.

In the poultry science area, Mariano et al. (2014) have developed a committee network to predict the AMEn of poultry, in which the mode of the empirical distribution was the estimator that ensured more accurate predictions for these energy values. Furthermore, they recommended its use because it allows associating some uncertainty with the prediction, using a highest probability density (HPD) interval. In the literature, studies have compared the use of neural networks and regression models in animal science, but not regression models to the committee networks for AMEn predictions.

The objective of this work was to compare the committee neural network $(\mathrm{CNN})$ and weighted multiple linear regression (WMLR) models, in order to estimate the nitrogen-corrected apparent metabolizable energy of poultry feedstuffs. Furthermore, besides considering the main effects and interactions between the explanatory variables to adjust the WMLR model, this work also sought to control the variability of the data set, creating a treatment variable by combining the levels of the categorical variables related to specifications of the feedstuff. These models were obtained for the rapid prediction of AMEn values of several concentrate feedstuffs commonly used in feeds for broilers.

\section{Materials and methods}

The dataset used to adjust the weighted multiple linear regression (WMLR) model was previously described by Nascimento et al. (2009). This dataset referring to 568 experimental results corresponds to 370 energetic concentrate samples and 198 protein concentrate samples evaluated in experiments carried out in Brazil from 1967 to 2007.

The test data used in the comparison of the models refer to 48 samples of energetic concentrate and protein concentrate feedstuffs, which were determined in metabolic bioassays conducted in the Poultry Section of the Departamento de Zootecnia, of the Universidade Federal de Lavras, in Lavras, Minas Gerais state, Brazil. Among these data are the experimental results described by Alvarenga et al. $(2011,2015)$. The protein feedstuffs used in those metabolic bioassays were samples from six commercial brands of soybean meal, 
one of semi-integral soybean meal, one of extruded whole soybean, one of textured soybean protein, two of integral micronized soy, two of maize gluten meal at $60 \%$, and one of a roasted whole soybean. The energetic feedstuffs included samples of four maize hybrids, three of sorghum, one of pre-gelatinized maize, one of broken maize, one of wheat meal, one of integral rice meal, one of broken rice, and one of defatted maize germ.

The observed values of apparent metabolizable energy (AMEn), chemical composition - crude protein (CP), ether extract (EE), ash, and crude fiber (CF) -, the classification of the feedstuff category ( 1 for energetic concentrate, 2 for protein concentrate), the type of ingredient ( 1 for maize, or soybean meal, and 2 for maize byproduct, or other soybean byproduct, and 3 for other feedstuff), and the type of animal used in the bioassay ( 1 for chick, and 2 for rooster) were defined for each feedstuff. All the feedstuffs considered are of plant origin, and are commonly used in poultry feeds.

In the present study, a multilayer-perceptron (MLP) committee neural network was considered, which was developed to predict AMEn values of energetic and protein concentrates for poultry (Mariano et al., 2014). All networks considered in the committee had the same MLP architecture 7-5-3-1, which represents: 7 inputs, 5 neurons in the first hidden layer, 3 neurons in the second hidden layer, and 1 output. The same training algorithm, Levenberg-Marquardt, was used in all settings, but with the initial weights and the division between the training and validation data randomly defined by the Matlab R2012b (The Mathworks Inc., Natick, Massachusetts, USA). The Matlab offers a very efficient ANN toolbox and, therefore, it was used to implement the networks.

After testing committees with different numbers of networks, the committee $\mathrm{N}=1,000$ networks guaranteed the most accurate predictions, and the mode estimator of the empirical distribution was used as the combinator of expert networks. The choice of this committee was based on the value of the $95.83 \%$ correct predictions. Further information on the development of this committee can be obtained from Mariano et al. (2014).

Mariano et al. (2012) proposed and evaluated some of the AMEn prediction equations of poultry feedstuffs based on their chemical composition. These prediction equations were adjusted by WMLR models, considering the principle of the meta-analysis, and the technique of principal components was used in the formation of homogeneous groups of experimental results. In the present work, a weighted multiple linear regression equation was adjusted following the methodology of Mariano et al. (2012), and using the set of 568 experimental results. Firstly, the TRAT variable was created by combining the levels of the categorical variables of the data set (feedstuff category, type of ingredient, and type of animal used in the bioassay). Thus, it the main effects and interactions between the explanatory variables (CP; EE; ash; CF; and TRAT) were considered in this model adjustment. EqPred denoted this prediction equation.

For comparison of the models considered in this paper, the percentage of correct predictions (PCP) in the test dataset was used. This percentage was obtained considering the frequency by which, in the test set, the observed values (real values) of the feedstuffs were within their respective intervals of prediction or of HPD.

The credibility intervals are the Bayesian correspondents to the confidence intervals in the classical approach. In general, the HPD interval is desirable, as it ensures that the interval is minimal (Carvalho, 2009). However, the construction of the HPD interval is usually based on samples from some distribution. In the present study, it is assumed that the empirical distribution approximates the desired distribution. Then, based on the property that HPD is the smallest of all ranges, the implementation finds the shortest range boundaries with the values of the ordered sample, considering the desired level of credibility, as presented by Ribeiro Jr et al. (2012).

For the WMLR model, the prediction confidence interval (Ferreira, 2009) was calculated for each feedstuff in the test set. For the committee networks, the HPD credible interval of predictions was considered, as the empirical distribution of the predictions coming from the neural networks that composed the committee was asymmetric (Ribeiro Jr et al., 2012). The level of confidence and/or credibility considered was $95 \%$.

The steps to obtain the HPD credible interval for each feedstuff in the test set were: (i) to consider the predictions corresponding to $\mathrm{N}=1,000$ committee networks; (ii) to obtain the empirical distribution of the 1,000 predictions of the feedstuff; (iii) to obtain, from the empirical distribution, the interval of smaller 
length that includes the points of highest density, that is, the HPD interval.

This way, the PCP can be expressed by the following ratio:

$$
\mathrm{PCP}=\sum_{\mathrm{i}=1}^{\mathrm{k}} \frac{\mathrm{I}\left(\mathrm{LI}_{\mathrm{i}} \leq \mathrm{Y}_{\mathrm{OBS}_{\mathrm{i}}} \leq \mathrm{LS}_{\mathrm{i}}\right)}{\mathrm{K}} \times 100,
$$

in which: I(.) is an indicator function bellow,

$$
\mathrm{I}(.)=\left\{\begin{array}{l}
1, \text { if } \mathrm{Y}_{\mathrm{OBS}_{\mathrm{i}}} \in \text { interval } \\
0, \text { othercase }
\end{array}\right.
$$

$\mathrm{LI}_{\mathrm{i}}$ and $\mathrm{LS}_{\mathrm{i}}$ are, respectively, the lower and upper limits of the prediction intervals, or the HPD credible intervals, calculated for the $i^{\text {th }}$ feedstuff; $\mathrm{Y}_{\mathrm{OBS}_{\mathrm{i}}}$ is the observed value of AMEn (real value) for the $i^{\text {th }}$ feedstuff; and $\mathrm{K}$ is the number of feedstuffs contained in the test set.

In the equation, it is said that there is no evidence that the predicted value is different from that observed, when the observed value of a feedstuff is within its respective interval, which should result in the success of this event. Thus, the calculation of the PCP is nothing more than an average of a simple random sample of a population with Bernoulli distribution.

The comparison of the obtained proportions in PCP was performed by applying the Pearson's asymptotic chi-squared test, as defined in Biase \& Ferreira (2009). The nullity hypothesis of this test is the equality of the binomial proportions $\mathrm{H}_{0}: \mathrm{PCP}_{1}=\mathrm{PCP}_{2}$, in which $\mathrm{PCP}_{\mathrm{i}}$ is the estimator of the correct proportion of each of the selected models. That is, $\mathrm{PCP}_{1}$ and $\mathrm{PCP}_{2}$ refer, respectively, to percentages of hits (successes) using the EqPred and the committee networks considered in the present study. By this test, it is possible to verify whether the proportions differ from each other. The statistic of this test has an asymptotic chi-squared distribution with $v=\mathrm{k}-1$ degrees of freedom, in which $\mathrm{k}$ is the number of populations (in the present study, the number of selected models). The adopted level of significance was $5 \%$ for the test of comparison of proportions.

The quality of the adjustment and the accuracy of the AMEn prediction models, from both the prediction equation and the committee networks, were evaluated with the test data. The statistics used in this process, based on the errors between observed and predicted AMEn values, were as follows: $\mathrm{R}^{2}$ (coefficient of determination), MSE (mean squared error), MAD (mean absolute deviation), MAPE (mean absolute percentage error) and bias (systematic deviation), as defined by Mariano et al. (2014) and Perai et al. (2010). Thus, the closer to one is the value of $\mathrm{R}^{2}$, the closer to zero is the bias value, and the smaller the values of MSE, MAPE, and MAD, the more accurate the model. All statistical analyses were performed in free software R (R Core Team, 2019).

\section{Results and discussion}

The EqPred model was adjusted, in order to search for a better predictive capacity among the usual statistical methods, considering the main effects and interactions between the explanatory variables. The adjustment of the proposed model is based on 12 regression equations (Table 1 ) due to the creation of the TRAT variable. Thus, TRAT $\mathrm{ijk}_{\mathrm{ijk}}$ represents the particular equation, when the feedstuff is related to the $\mathrm{i}^{\text {th }}$ feedstuff category, the $\mathrm{j}^{\text {th }}$ type of ingredient, and the $\mathrm{k}^{\text {th }}$ type of animal, in which: $\mathrm{i}=1$, energetic concentrate; or 2, protein concentrate; $\mathrm{j}=1$, maize, or soybean meal; 2 , maize byproduct, or other soybean byproduct; 3 , other feedstuff; $\mathrm{k}=1$, chick, or 2, rooster.

The models selected in the present study - EqPred and committee neural network - were developed for the prediction of AMEn of both energetic and protein concentrate feedstuffs. The use of these models is still more appropriate to estimate the AMEn of feedstuffs such as maize, sorghum, soybean, soybean meal, wheat and wheat meal (Mariano et al., 2012, 2013). These models were indicated because these feedstuffs had greater representativeness in the dataset used in the development of the models.

For the committee networks model, HPD intervals were considered, as the empirical distribution of predictions, coming from the 1,000 neural networks that composed the committee, was asymmetric. This way, the best interval to be calculated was the prediction credibility interval that included the points of highest density and shorter length, that is, the HPD interval (Ribeiro Jr et al., 2012). For the prediction equation models, intervals of prediction (IP) were considered, which can also be defined as HPD intervals, since they correspond to the smallest interval of maximum coverage due to the normal symmetrical distribution assumed by the use of multiple linear regression. 
The observed AMEn values in metabolic assays and their respective intervals referring to the models considered in this study are presented in Table 2 . These intervals were calculated for the 48 feedstuffs of the test set. The mean amplitude of the HPD credible intervals was higher than the mean amplitude of the prediction intervals. The estimation of the HPD credible intervals allowed of the association of some uncertainty to the predicted values, increasing the reliability in the committee neural networks. In addition, constructed intervals were used as control limits to verify the PCP of the selected models (Table 3).

The equality of the binomial proportions was verified by Pearson's asymptotic chi-squared test, which showed a significant result among the proportions (p-value <0.01). Therefore, the PCP obtained with the use of the committee networks was observed as greater than the proportion of successes obtained by the EqPred prediction equation (Table 3).

Statistical results associated to the models selected in this paper for the prediction of AMEn values of feedstuffs for broilers are presented in Table 4. The committee neural networks shows the lowest values for MAD, MAPE, and MSE, as well as $\mathrm{R}^{2}$ valuecloserto one, and bias closer to zero, than the EqPred. These results, obtained by the suitability criteria of models, showed that the committee networks provide more accurate predictions against the adjusted WMLR model, which is consistent with the fact that the committee model guarantees a higher PCP. Furthermore, the tendency of independent variables to be strongly correlated with one another and the existence of even significant quadruple interactions make the practical application of EqPred unfeasible for nutritionists of animal sector. In contrast, in the committee model, it is possible to use many variables that interfere in the variability of metabolizable energy, which is not always feasible in a multiple regression model.

Therefore, the committee model composed of $\mathrm{N}=1,000$ networks, considering as best estimator the empirical mode of the predictions, had a good generalization, and will be made available for use with new input data. For this, an easy to use tool, created by Mariano et al. (2013), can be improved for nutritionists of the animal area.

In the comparison of the predicted value with the real value, it was observed that the values predicted by the committee networks tended to follow the same patterns as the observed data, since points near the identity line indicate that the predicted values are more similar to those observed (Figure 1). In other words, it was possible to verify the good adjustment of the model for the prediction of AMEn of energetic and

Table 1. Specific prediction equations for apparent metabolizable energy (AMEn) values of feedstuffs for broilers, for each combination of TRAT $_{\mathrm{ijk}}$ variable.

\begin{tabular}{lc}
\hline TRAT $_{\text {ijk }}{ }^{(1)}$ & Specific equation \\
\hline TRAT $_{111}$ & $3,196.898+111.127 \mathrm{EE}+69.109 \mathrm{ash}-28.856 \mathrm{CF}+41.740 \mathrm{CP}-13.987 \mathrm{EE} \times \mathrm{CP}+2.699 \mathrm{ash} \times \mathrm{CP}+8.107 \mathrm{CF} . \mathrm{CP}+0.362 \mathrm{EE} \times \mathrm{ash} \times \mathrm{CP}$ \\
$\mathrm{TRAT}_{112}$ & $2,605.700+111.127 \mathrm{EE}+69.109 \mathrm{ash}-28.856 \mathrm{CF}+148.109 \mathrm{CP}-8.423 \mathrm{EE} \times \mathrm{CP}-62.111 \mathrm{ash} \times \mathrm{CP}+8.297 \mathrm{CF} \times \mathrm{CP}+2.381 \mathrm{EE} \times \mathrm{ash} \times \mathrm{CP}$ \\
$\mathrm{TRAT}_{121}$ & $2,605.067+111.127 \mathrm{EE}+69.109 \mathrm{ash}-28.856 \mathrm{CF}+213.263 \mathrm{CP}-22.078 \mathrm{EE} . \mathrm{CP}-21.278 \mathrm{ash} . \mathrm{CP}-10.972 \mathrm{CF} . \mathrm{CP}+2.888 \mathrm{EE} \times \mathrm{ash} \times \mathrm{CP}$ \\
$\mathrm{TRAT}_{122}$ & $8,651.232+111.127 \mathrm{EE}+69.109 \mathrm{ash}-28.856 \mathrm{CF}-755.557 \mathrm{CP}+8.571 \mathrm{EE} \times \mathrm{CP}+13.079 \mathrm{ash} \times \mathrm{CP}+14.284 \mathrm{CF} \times \mathrm{CP}$ \\
$\mathrm{TRAT}_{131}$ & $3,272.000+111.127 \mathrm{EE}+69.109 \mathrm{ash}-28.856 \mathrm{CF}+38.562 \mathrm{CP}-7.965 \mathrm{EE} . \mathrm{CP}-5.603 \mathrm{ash} \times \mathrm{CP}-6.819 \mathrm{CF} \times \mathrm{CP}+0.200 \mathrm{EE} \times \mathrm{ash} \times \mathrm{CP}$ \\
$\mathrm{TRAT}_{132}$ & $3,670.277+111.127 \mathrm{EE}+69.109 \mathrm{ash}-28.856 \mathrm{CF}-72.692 \mathrm{CP}+7.042 \mathrm{EE} . \mathrm{CP}+0.046 \mathrm{ash} \times \mathrm{CP}-6.248 \mathrm{CF} \times \mathrm{CP}-1.088 \mathrm{EE} \times \mathrm{ash} \times \mathrm{CP}$ \\
$\mathrm{TRAT}_{211}$ & $1,530.008+111.127 \mathrm{EE}+69.109 \mathrm{ash}-28.856 \mathrm{CF}-16.175 \mathrm{CP}+14.131 \mathrm{EE} . \mathrm{CP}+3.377 \mathrm{ash} \times \mathrm{CP}+1.456 \mathrm{CF} \times \mathrm{CP}-2.595 \mathrm{EE} \times \mathrm{ash} \times \mathrm{CP}$ \\
$\mathrm{TRAT}_{212}$ & $965.120+111.127 \mathrm{EE}+69.109 \mathrm{ash}-28.856 \mathrm{CF}+79.883 \mathrm{CP}-17.111 \mathrm{EE} . \mathrm{CP}-9.414 \mathrm{ash} \times \mathrm{CP}+1.403 \mathrm{CF} \times \mathrm{CP}+2.183 \mathrm{EE} \times \mathrm{ash} \times \mathrm{CP}$ \\
$\mathrm{TRAT}_{221}$ & $718.556+111.127 \mathrm{EE}+69.109 \mathrm{ash}-28.856 \mathrm{CF}+17.382 \mathrm{CP}-0.810 \mathrm{EE} . \mathrm{CP}+1.609 \mathrm{ash} \times \mathrm{CP}+0.802 \mathrm{CF} \times \mathrm{CP}-0.0193 \mathrm{EE} \times \mathrm{ash} \times \mathrm{CP}$ \\
$\mathrm{TRAT}_{222}$ & $-1,057.607+111.127 \mathrm{EE}+69.109 \mathrm{ash}-28.856 \mathrm{CF}+33.665 \mathrm{CP}+5.233 \mathrm{EE} . \mathrm{CP}+5.440 \mathrm{ash} \times \mathrm{CP}+2.567 \mathrm{CF} \times \mathrm{CP}-1.234 \mathrm{EE} \times \mathrm{ash} \times \mathrm{CP}$ \\
$\mathrm{TRAT}_{231}$ & $991.734+111.127 \mathrm{EE}+69.109 \mathrm{ash}-28.856 \mathrm{CF}+42.695 \mathrm{CP}+0.467 \mathrm{EE} . \mathrm{CP}-3.750 \mathrm{ash} \times \mathrm{CP}+0.312 \mathrm{CF} \times \mathrm{CP}-0.295 \mathrm{EE} \times \mathrm{ash} \times \mathrm{CP}$ \\
$\mathrm{TRAT}_{232}$ & $4,586.733+111.127 \mathrm{EE}+69.109 \mathrm{ash}-28.856 \mathrm{CF}+31.285 \mathrm{CP}-4.715 \mathrm{EE} . \mathrm{CP}-24.654 \mathrm{ash} \times \mathrm{CP}+3.502 \mathrm{CF} \times \mathrm{CP}$ \\
\hline
\end{tabular}

${ }^{(1)} \mathrm{TRAT}_{\mathrm{ijk}}$ represents the specific equation when the feedstuff is related to the $\mathrm{i}^{\text {th }}$ feedstuff category, to the $\mathrm{j}^{\text {th }}$ type of ingredient, and to the $\mathrm{k}^{\text {th }}$ type of animal, in which: $i=1$, energetic concentrate, or 2, protein concentrate; $j=1$, maize or soybean meal, or 2 , maize byproduct or other soybean byproduct, or 3 , other feedstuff; $\mathrm{k}=1$, chick, or 2, rooster. ${ }^{(2)}$ Chemical composition values of the respectively selected feedstuff: crude protein (CP); ether extract without acid hydrolysis (EE); ash; and crude fiber (CF). 
Table 2. Observed values, intervals of prediction (IP), and the highest probability density (HPD) credible intervals, related to the test dataset of apparent metabolizable energy (AMEn) prediction models of poultry feedstuffs ${ }^{(1)}$.

\begin{tabular}{|c|c|c|c|}
\hline Feedstuff & $\begin{array}{l}\text { Observed } \\
\text { AMEn }\end{array}$ & EqPred $^{(2)}(\mathrm{IP})$ & $\begin{array}{c}\text { ANN com- } \\
\text { mittee }^{(3)} \text { (HPD) }\end{array}$ \\
\hline Maize 1 & 3,699 & {$[3,691 ; 3,748]$} & {$[3,538 ; 3,803]$} \\
\hline Maize 2 & 3,813 & {$[3,674 ; 3,754]$} & {$[3,538 ; 3,832]$} \\
\hline Sorghum 1 & 3,529 & {$[3,452 ; 3,563]$} & {$[3,213 ; 3,721]$} \\
\hline Sorghum 2 & 3,598 & {$[3,463 ; 3,585]$} & {$[3,184 ; 3,707]$} \\
\hline Broken rice & 3,862 & {$[3,572 ; 3,749]$} & {$[3,204 ; 3,818]$} \\
\hline Integral rice meal & 2,682 & {$[2,679 ; 3,628]$} & {$[2,075 ; 3,677]$} \\
\hline Pre-gelatinized maize & 3,624 & {$[3,719 ; 4,314]$} & {$[3,212 ; 3,984]$} \\
\hline Wheat meal & 1,941 & {$[2,081 ; 2,403]$} & {$[1,722 ; 2,791]$} \\
\hline Broken maize & 3,676 & {$[3,596 ; 3,889]$} & {$[3,213 ; 3,840]$} \\
\hline Soybean meal 1 & 2,326 & {$[2,007 ; 3,064]$} & {$[2,207 ; 3,112]$} \\
\hline Soybean meal 2 & 2,355 & {$[1,971 ; 2,902]$} & {$[2,263 ; 3,005]$} \\
\hline Soybean meal 3 & 2,396 & {$[1,722 ; 3,116]$} & {$[2,184 ; 3,048]$} \\
\hline Soybean meal 4 & 2,478 & {$[1,922 ; 2,984]$} & {$[2,254 ; 3,047]$} \\
\hline Semi-integral soybean meal & 3,159 & {$[2,602 ; 3,466]$} & {$[2,349 ; 3,976]$} \\
\hline Full-fat extruded soybean & 3,779 & {$[3,225 ; 4,171]$} & {$[3,073 ; 3,906]$} \\
\hline Texturized soybean protein & 2,809 & {$[2,040 ; 3,161]$} & {$[2,254 ; 3,410]$} \\
\hline Integral micronized soy 1 & 3,772 & {$[3,437 ; 4,684]$} & {$[3,204 ; 4,407]$} \\
\hline Maize gluten meal 1 & 3,934 & {$[3,536 ; 4,436]$} & {$[2,851 ; 4,212]$} \\
\hline Maize 3 & 3,591 & {$[3,774 ; 3,857]$} & {$[3,538 ; 3,831]$} \\
\hline Sorghum 3 & 3,353 & {$[3,501 ; 3,634]$} & {$[3,179 ; 3,709]$} \\
\hline Defatted corn germ meal & 2,248 & {$[1,493 ; 3,212]$} & {$[1,668 ; 3,604]$} \\
\hline Soybean meal 5 & 2,387 & {$[2,302 ; 3,051]$} & {$[2,203 ; 3,277]$} \\
\hline Maize gluten meal 2 & 3,700 & {$[3,597 ; 4,419]$} & {$[2,851 ; 4,238]$} \\
\hline Integral micronized soy 2 & 3,971 & {$[3,513 ; 4,170]$} & {$[3,254 ; 3,969]$} \\
\hline Roasted whole soybean & 3,288 & {$[3,055 ; 4,325]$} & {$[2,882 ; 3,969]$} \\
\hline Maize 3 & 3,568 & {$[3,774 ; 3,857]$} & {$[3,538 ; 3,831]$} \\
\hline Sorghum 3 & 3,297 & {$[3,501 ; 3,634]$} & {$[3,179 ; 3,709]$} \\
\hline Defatted corn germ meal & 2,151 & {$[1,493 ; 3,212]$} & {$[1,668 ; 3,604]$} \\
\hline Soybean meal 5 & 2,314 & {$[2,302 ; 3,051]$} & {$[2,203 ; 3,277]$} \\
\hline Maize gluten meal 2 & 3,941 & {$[3,597 ; 4,419]$} & {$[2,851 ; 4,238]$} \\
\hline Integral micronized soy 2 & 3,818 & {$[3,513 ; 4,170]$} & {$[3,254 ; 3,969]$} \\
\hline Roasted whole soybean & 3,173 & {$[3,055 ; 4,325]$} & {$[2,882 ; 3,969]$} \\
\hline Maize 3 & 3,581 & {$[3,774 ; 3,857]$} & {$[3,538 ; 3,831]$} \\
\hline Sorghum 3 & 3,436 & {$[3,501 ; 3,634]$} & {$[3,179 ; 3,709]$} \\
\hline Defatted corn germ meal & 2,173 & {$[1,493 ; 3,212]$} & {$[1,668 ; 3,604]$} \\
\hline Soybean meal 5 & 2,339 & {$[2,302 ; 3,051]$} & {$[2,203 ; 3,277]$} \\
\hline Maize gluten meal 2 & 3,954 & {$[3,597 ; 4,419]$} & {$[2,851 ; 4,238]$} \\
\hline Integral micronized soy 2 & 3,793 & {$[3,513 ; 4,170]$} & {$[3,254 ; 3,969]$} \\
\hline Roasted whole soybean & 3,330 & {$[3,055 ; 4,325]$} & {$[2,882 ; 3,969]$} \\
\hline Maize 3 & 3,548 & {$[3,774 ; 3,857]$} & {$[3,538 ; 3,831]$} \\
\hline Sorghum 3 & 3,363 & {$[3,501 ; 3,634]$} & {$[3,179 ; 3,709]$} \\
\hline Defatted corn germ meal & 2,162 & {$[1,493 ; 3,212]$} & {$[1,668 ; 3,604]$} \\
\hline Soybean meal 5 & 2,309 & {$[2,302 ; 3,051]$} & {$[2,203 ; 3,277]$} \\
\hline Maize gluten meal 2 & 4,022 & {$[3,597 ; 4,419]$} & {$[2,851 ; 4,238]$} \\
\hline Integral micronized soy 2 & 3,890 & {$[3,513 ; 4,170]$} & {$[3,254 ; 3,969]$} \\
\hline Roasted whole soybean & 3,267 & {$[3,055 ; 4,325]$} & {$[2,882 ; 3,969]$} \\
\hline Maize 4 & 3,747 & {$[3,639 ; 3,793]$} & {$[3,537 ; 3,828]$} \\
\hline Soybean meal 6 & 2,373 & {$[2,219 ; 2,850]$} & {$[2,337 ; 3,057]$} \\
\hline Mean amplitude & & 723.741 & 934.521 \\
\hline
\end{tabular}

(1)Interval in bold represents that there is no evidence that the observed value differs from the predicted value by the model for the respective feedstuff. ${ }^{(2)}$ The EqPred was obtained using the methodology proposed in the present work. ${ }^{(3)}$ The model committee artificial neural networks (ANN) was obtained from Mariano et al. (2014). protein concentrates in feedstuffs, commonly used in the formulation of feeds for broilers.

Table 3. Percentage of correct predictions (PCP) of models for the prediction of apparent metabolizable energy (AMEn) values of feedstuffs for broilers, considering test data obtained in metabolic bioassay ${ }^{(1)}$.

\begin{tabular}{lc}
\hline Models $^{(2)}$ & PCP (\%) \\
\hline EqPred & $72.92 \mathrm{a}$ \\
Committee ANN & $95.83 \mathrm{~b}$ \\
\hline
\end{tabular}

(1)Percentages followed by equal letters, do not differ from each other by Pearson's asymptotic chi-squared test for comparison of proportions, at 5\% probability. ${ }^{(2)}$ The model of neural networks was obtained from Mariano et al. (2014). The equation EqPred was obtained using the methodology proposed in this paper.

Table 4. Adequacy of the adjustment and accuracy of the selected models.

\begin{tabular}{lcc}
\hline Statistics $^{(1)}$ & \multicolumn{2}{c}{ Models $^{(2)}$} \\
\cline { 2 - 3 } & EqPred & ANN committee \\
\hline $\mathrm{R}^{2}$ & 0.87 & 0.89 \\
MSE & $54,629.21$ & $45,285.43$ \\
MAD & 190.83 & 175.66 \\
MAPE (\%) & 6.52 & 5.97 \\
Bias & -146.67 & -86.80 \\
\hline
\end{tabular}

${ }^{(1)} \mathrm{R}^{2}$, coefficient of determination; MSE, mean squared error; MAD, mean absolute deviation; MAPE, mean absolute percentage error; bias. ${ }^{(2)}$ The model of neural networks was obtained from Mariano et al. (2014). The equation EqPred was obtained using the methodology proposed in the present work.

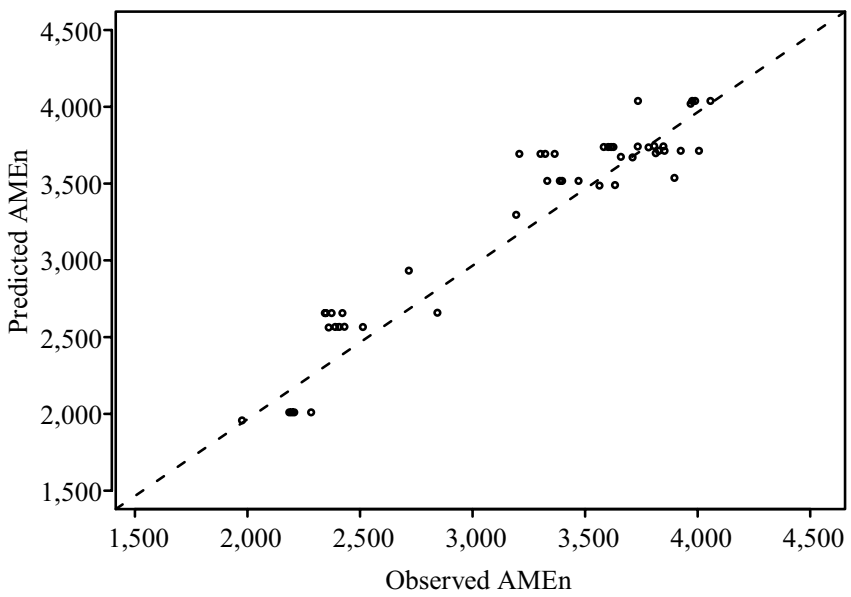

Figure 1. Predicted vs observed apparent metabolizable energy (AMEn) values obtained in the test data for concentrate feedstuffs for broilers, via committee neural networks. 
The results obtained in this work reinforce the conclusions of previous studies that the use of models related to ANN guarantees more accurate predictions than those obtained by classical statistical methods, in the area of nutrition and animal production. Perai et al. (2010) noted that the ANN model produced more accurate predictions of true metabolizable energy (TMEn) values of meat and bone meal samples than the partial least square models and multiple linear regression. Wang et al. (2012) showed that the ANN method is more accurate than traditional regression models for predicting egg production in Taiwan. Ahmadi \& Golian (2010) verified that the radial basis functions neural networks model (RBFN) showed more accurate predictions of broiler growth than those obtained by multiple regression models; these broilers fed diets with different percentages of metabolizable energy provided by protein, fat, and carbohydrate.

For future studies, the use some method that makes it possible to evaluate the significance of input variables should be considered in the expert networks that will compose the committee, such as Bayesian networks. The objective is to improve the accuracy of the committee network model, in the prediction of AMEn for concentrate feedstuffs used in the formulation of poultry feeds. Furthermore, new regression models should be adjusted, and a more detailed analysis about prediction intervals should be considered.

\section{Conclusions}

1. The use of the committee neural networks show more accurate predictions of apparent metabolizable energy of energetic and protein concentrates, in feedstuffs commonly used in the formulation of feeds for broilers, than those obtained by the prediction equation adjusted by a weighted multiple linear regression model.

2. The committee with $\mathrm{N}=1,000$ networks, using the mode of the empirical distribution of the predictions in the combination of the results, guarantees a greater accuracy in the prediction of the test set.

\section{Acknowledgments}

To Coordenação de Aperfeiçoamento de Pessoal de Nível Superior (Capes), for scholarship granted (Finance code 001).

\section{References}

AHMADI, H.; GOLIAN, A. Growth analysis of chickens fed diets varying in the percentage of metabolizable energy provided by protein, fat, and carbohydrate through artificial neural network. Poultry Science, v.89, p.173-179, 2010. DOI: https://doi.org/10.3382/ps.2009-00125.

ALVARENGA, R.R.; RODRIGUES, P.B.; ZANGERONIMO, M.G.; FREITAS, R.T.F.; LIMA, R.R.; BERTECHINI, A.G.; FASSANI, E.J. Energetic values of feedstuffs for broilers determined with in vivo assays and prediction equations. Animal Feed Science and Technology, v.168, p.257-266, 2011. DOI: https://doi.org/10.1016/j.anifeedsci.2011.04.092.

ALVARENGA, R.R.; RODRIGUES, P.B.; ZANGERONIMO, M.G.; OLIVEIRA, E.C.; MARIANO, F.C.M.Q.; LIMA, E.M.C.; GARCIA JR., A.A.P.; NAVES, L.P.; NARDELLI, N.B.S. Validation of prediction equations of energy values of a single ingredient or their combinations in male broilers. AsianAustralasian Journal of Animal Sciences, v.28, p.1335-1344, 2015. DOI: https://doi.org/10.5713/ajas.14.0339.

ANYAECHE, C.O;; IGHRAVWE, D.E. Predicting performance measures using linear regression and neural network: a comparison. African Journal of Engineering Research, v.1, p.84-89, 2013.

BIASE, N.G.; FERREIRA, D.F. Comparações múltiplas e testes simultâneos para parâmetros binomiais de $\mathrm{k}$ populações independentes. Revista Brasileira de Biometria, v.27, p.301-323, 2009.

CARVALHO, D.C. de O. Gráficos de controle Bayesianos em alguns processos da família exponencial. 2009. 47p. Dissertação (Mestrado) - Universidade Federal do Pará, Belém.

FERREIRA, D.F. Estatística básica. 2.ed. rev. Lavras: UFLA, 2009. 663p.

HAYKIN, S. Neural networks: a comprehensive foundation. Upper Saddle River: Prentice Hall, 2007.

MARIANO, F.C.M.Q.; LIMA, R.R. de; RODRIGUES, P.B.; ALVARENGA, R.R.; NASCIMENTO, G.A.J. do. Equações de predição de valores energéticos de alimentos obtidas utilizando meta-análise e componentes principais. Ciência Rural, v.42, p.1634-1640, 2012. DOI: https://doi.org/10.1590/S010384782012005000061 .

MARIANO, F.C.M.Q.; LIMA, R.R.; ALVARENGA, R.R.; RODRIGUES, P.B.; LACERDA, W.S. Neural network committee to predict the AMEn of poultry feedstuffs. Neural Computing and Applications, v.25, p.1903-1911, 2014. DOI: https://doi.org/10.1007/s00521-014-1680-3.

MARIANO, F.C.M.Q.; PAIXÃO, C.A.; LIMA, R.R.; ALVARENGA, R.R.; RODRIGUES, P.B.; NASCIMENTO, G.A.J. Prediction of the energy values of feedstuffs for broilers using meta-analysis and neural networks. Animal, v.7, p.14401445, 2013. DOI: https://doi.org/10.1017/S1751731113000712.

NASCIMENTO, G.A.J. do; RODRIGUES, P.B.; FREITAS, R.T.F. de; BERTECHINI, A.G.; LIMA, R.R. de; PUCCI, L.E.A. Equações de predição para estimar os valores energéticos de 
alimentos concentrados de origem vegetal para aves utilizando a metanálise. Revista Brasileira de Zootecnia, v.38, p.1265-1271, 2009. DOI: https://doi.org/10.1590/S1516-35982009000700015.

NASCIMENTO, G.A.J.; RODRIGUES, P.B.; FREITAS, R.T.F.; REIS NETO, R.V.; LIMA, R.R.; ALLAMAN, I.B. Equações de predição para estimar valores da energia metabolizável de alimentos concentrados energéticos para aves utilizando meta-análise. Arquivo Brasileiro de Medicina Veterinária e Zootecnia, v.63, p.222-230, 2011. DOI: https://doi.org/10.1590/ S0102-09352011000100032.

PERAI, A.H.; MOGHADDAM, H.N.; ASADPOUR, S.; BAHRAMPOUR, J.; MANSOORI, G. A comparison of artificial neural networks with other statistical approaches for the prediction of true metabolizable energy of meat and bone meal. Poultry Science, v.89, p.1562-1568, 2010. DOI: https://doi.org/10.3382/ ps.2010-00639.

R CORE TEAM. R: a language and environment for statistical computing. Vienna: R Foundation for Statistical Computing, 2019. Software.
RIBEIRO JR, P.J.; BONAT, W.H.; KRAINSKI, E.T.; ZEVIANI, W.M. Métodos computacionais para inferência estatística. In: SIMPÓSIO NACIONAL DE PROBABILIDADE E ESTATÍSTICA, 20., 2012, João Pessoa. Minicurso. João Pessoa: Associação Brasileira de Estatística, 2012.

RODRIGUES, P.B.; ROSTAGNO, H.S.; ALBINO, L.F.T.; GOMES, P.C.; NUNES, R.V.; TOLEDO, R.S. Valores energéticos da soja e subprodutos da soja, determinados com frangos de corte e galos adultos. Revista Brasileira de Zootecnia, v.31, p.1771-1782, 2002. DOI: https://doi.org/10.1590/s1516-35982002000700020.

SHI, H.-Y.; LEE, K.-T.; LEE, H.-H.; HO, W.-H.; SUN, D.-P.; WANG, J.-J.; CHIU, C.-C. Comparison of artificial neural network and logistic regression models for predicting in-hospital mortality after primary liver cancer surgery. PLoS ONE, v.7, e35781, 2012. DOI: https://doi.org/10.1371/journal.pone.0035781.

WANG, B.Y.; CHEN, S.A.; ROAN, S.W. Comparison of regression and artificial neural network models of egg production. Journal of Animal and Veterinary Advances, v.11, p.2503-2508, 2012. DOI: https://doi.org/10.3923/javaa.2012.2503.2508. 